\title{
1. Introduction: The life of international law and its concepts
}

\section{Sahib Singh and Jean d'Aspremont}

'What meaning has the concept of murder, when we are confronted with the mass production of corpses?' ${ }^{\prime}$ Hannah Arendt asks this question of her readers as she attempts to understand the workings of totalitarianism. It may, though, also sound apt for today's international law and its concepts. Contemporary international lawyers ply their trade knowing full well that significant parts of this law are structurally implicated in and perpetuate on-going economic and social injustices. Yet lawyers idealistically and increasingly resort to international law's promises. How could our greater recourse to concepts such as universality, aggression, development, humanity or rights (to name but a few) not be tinged with a sense of futility? But this would miss Arendt's point, for her question is a critique of how we are prone to think with concepts. Recourse to the concept of murder in order to understand, explain and evaluate the known horrors of the concentration camps meant giving in to a certain common sense. It was to concede to the 'great temptation to explain away the intrinsically incredible by means of liberal rationalizations' ${ }^{2}$ Modes of thought or attitudes that seek to reduce the complexities (and horrors) of our social world to inadequate categories are not merely unwarranted but potentially dangerous. It is, after all, not inadequate concepts or attempts to grasp the ungraspable and infinitely complex that Arendt indicts, but rather those who would do so by turning away from life and hence responsibility. ${ }^{3}$ Rather the question becomes: may we think of the relation(s) between concepts, life and living in international law?

We broach this question in three sections. First we explore the contemporary condition of international legal life in and from which this book emerges. We situate the project and pose the question of whether certain styles of conceptualization may offer a route out of our current malaise. Second, we offer a brief historical overview of how legal thought has approached legal concepts. The aim is to draw attention to those

H. Arendt, The Origins of Totalitarianism (3rd edn, Harcourt Brace \& Co 1973) 441. ibid, 439-40.

3 H. Arendt, 'The Aftermath of Nazi Rule' in J. Kohn (ed), Essays in Understanding 1930-1954: Formation, Exile and Totalitarianism (Schocken 2005) 250. Whether we consider her work on totalitarianism or that on revolution, Arendt structures much of her work around concepts. A philosophy of understanding, modest critique and a refusal to abide by theories informed her approach. See eg M. Lara, The Disclosure of Politics: Struggles over the Semantics of Secularization (Columbia University Press 2013) 29-58, 99-124. But it is not her methods or her position on concepts such as imperialism, humanity or the state that interests us; rather, it is her intuition that conceptual work and concepts must move towards life, especially so in times of horror and crisis. 
sensibilities that remain prevalent in today's legal writings, while also bringing attention to the limits, nuances and fractures in these sensibilities. Here, we offer detailed readings, criticisms and extensions of texts by Jhering, Hohfeld, Ross, Cohen, Kennedy and Koskenniemi, to name but a few. We argue that these writings offer various and contrasting aesthetic, ethical and political insights into how we live with, apprehend, think of and know international law through its concepts. These insights tend to emerge with considerable strength when we look at the tensions and differences between sensibilities side by side. Finally, it is perhaps clear by now that we intend this introduction to be a standalone piece. Nevertheless, the third section is a brief introduction to the volume itself. It outlines how we chose the concepts that comprise this volume, the types of concepts contained herein, how authors approached their given task and how we see relations between the various concepts contained in the book and the many that lie beyond its limited purview.

\section{INTERNATIONAL LAW'S PRECARIOUS LIFE}

International law seems to be living a precarious life. ${ }^{4}$ For many international lawyers writing today, confidence, if not faith, in the international legal project seems to be faltering. It seems increasingly difficult to sustain our commitment to that distinctly liberal cosmopolitan project of the pursuit of universality, progress, peace and justice in the service of humanity. Modernity's twin motors - reason and imagination - appear equally suspect. Scepticism and suspicion have cast long shadows over confidence. In significant part this is due to compelling postcolonial and critical works that detail how international law has been and remains structurally complicit in and responsible for much of today's injustice, inequality and violence. ${ }^{5}$ And both inescapable and implicated in this state of affairs are some (and many more) of the aforementioned normative commitments, categories of thought and universals. These anxieties sit alongside and are exacerbated by others. International law's apparent loss of centre, its apparent 'fragmentation', the porosity of its normative boundaries, all seem to accompany its material expansion and simultaneous marginalization. ${ }^{6}$ Even as international institutions, lawyers, norms and projects proliferate, international law has been subordinated to economic and political considerations. And where a broadly common (if varied) project and a common

4 There is a clear parallel to Judith Butler's seminal work, even though we do not use or pursue her concept of precarity. See J. Butler, Precarious Life: The Powers of Mourning and Violence (Verso 2004).

5 Seminal works include: A. Anghie, Sovereignty, Imperialism and International Law (Cambridge University Press 2003); C. Miéville, Between Equal Rights: A Marxist Theory of International Law (Brill 2005); S. Marks, 'Exploitation as an International Legal Concept' in S. Marks (ed), International Law on the Left: Re-Examining Marxist Legacies (Cambridge University Press 2008) 281-307; S. Marks, 'Human Rights and Root Causes' (2011) 74 Modern Law Review 57; S. Pahuja, Decolonising International Law: Development, Economic Growth and the Politics of Universality (Cambridge University Press 2011).

6 For an excellent take, see M. Prost, The Concept of Unity in Public International Law (Hart 2012) 4-14. For the anxieties regarding the loss of a centre and legal authority, see A. Orford, 'The Destiny of International Law' (2004) 11 Leiden Journal of International Law 441. 
language were seen to have existed, international lawyers seemed to find competing projects, semantic silos and symbolic struggles. ${ }^{7}$ These are, in sum, the root causes of today's existential malaise.

Responses have been vast and varied. Here we want to briefly focus on two: mastery and therapy. Though each rests on disciplinary introspection, these styles differ in their technical modes of reasoning, ethos and telos. Where mastery seeks certainty or surety, therapy pursues confidence. ${ }^{8}$ Questions of how we ended up here, what went wrong, how our state of affairs may be otherwise and what remains of our ideals are interspersed with the need to revisit international law as a vocation and a field filled with varied ways of thinking and being. These are the concerns being rapaciously consumed by the turn to disciplinary histories and sociologies in the service of therapy, ${ }^{9}$ able to offer a sense of perspective and possibilities of seeing projects and images of the discipline in other ways, to soothe our contemporary worries and, in some cases, to provide a sense of resolve. Other scholars have opted for the short-lived, and perhaps false, confidence that comes with illusions of certainty. Boundaries are hardened against all evidence of their porosity - legality is essentialized, disciplinary autonomy is staunchly defended based on loose notions of 'practice' - order is urged amid what Walker aptly termed the 'disorder of normative orders', 10 tradition is harnessed to urge loyalty and new foundations are asserted in the search for better theoretical models. ${ }^{11}$ Mastery rests on the desire to tame our complex social world. Therapy at its best - that is, when it resists nostalgia - understands international

7 For a critique of this anxiety and the resulting need for control, see S. Singh, 'Narrative and Theory: Formalism's Recurrent Return' (2014) 84 British Yearbook of International Law 304.

8 On the ethical distinction between confidence and certainty, see B. Williams, Ethics and the Limits of Philosophy (Harvard University Press 1985) 169-73. This is further developed in chapter 1 of S. Singh, Critique in Times of Crisis (PhD Thesis, University of Cambridge).

9 The classic contemporary trigger for the historical turn is M. Koskenniemi, The Gentle Civilizer of Nations: The Rise and Fall of International Law 1870-1960 (Cambridge University Press 2001). Recent disciplinary sociologies can be seen in A. Bianchi, International Law Theories: An Inquiry into Different Ways of Thinking (Oxford University Press 2016); W. Werner, 'Concluding Remarks: The Praxis of International Law' in J. d'Aspremont and others (eds), International Law as a Profession (Cambridge University Press 2017) 428.

10 N. Walker, 'Beyond Boundary Disputes and Basic Grids: Mapping the Global Disorder of Normative Orders' (2008) 6 International Journal of Constitutional Law 373.

11 On the reassertion of boundaries and autonomy, see P. Weil, 'Towards Relative Normativity in International Law?' (1983) 77 American Journal of International Law 413; J. Klabbers, 'The Relative Autonomy of International Law or the Forgotten Politics of Interdisciplinarity' (2004) 1 Journal of International Law and International Relations 35. On the rage for order and the turn to tradition, see J. Crawford, 'International Law as a Discipline and Profession' (2012) 106 Proceedings of the American Society of International Law 471; J. Crawford, 'Chance, Order, Change: The General Course on Public International Law' (2013) 365 Recueil des Cours de l'Académie de Droit International 9. On the need for better models in scholarship (and this being a form of creativity), see A. Peters, 'International Legal Scholarship Under Challenge' in J. d'Aspremont and others (n 9) 117. 
lawyers do not possess this power. We can perhaps only, and more modestly, find and choose better and more confident ways of living within and with this complexity. ${ }^{12}$

This medical trope of condition, symptom, treatment is not merely a context in which this book emerges and engages, ${ }^{13}$ it is also the structure of international lawyers' thinking about and treatment of concepts. As context, it is within this trope and contemporary condition that this book is situated. Naturally, it has affected the concepts we chose to examine, and it requires us to ask: How has our vocabulary changed with international law's contemporary challenges and the resultant introspection? How have older concepts been deployed in new ways; how have new concepts emerged? How are they entwined with power? And above all, may such work, if approached with a certain style and ethos, offer any insight into or route out of our contemporary malaise?

\section{LAW, LIFE, LIVING AND LEGAL CONCEPTS: SENSIBILITIES OF LEGAL THOUGHT}

History has made us acutely aware of the stakes when it comes to concepts. The struggle for law and legal thought has, in part, been waged over two concerns: how are legal concepts to be approached, and what role ought such concepts have in a given legal system. The past two centuries saw critiques of pandectism and begriffsjurisprudenz in nineteenth and twentieth-century Germany; American and Scandinavian legal realist scholars extended the critique of conceptual abstractions in several directions; and critical legal scholars have scrutinized the intimate relations between legal concepts and power over the past several decades. What follows is a brief sketch of this history. It foregrounds those legal sensibilities that remain (despite the passage of history's lessons) prominent in today's various approaches to concepts and highlights some of their nuances, difficulties and tensions.

Let us begin in Germany. Pandectism was perhaps most famously associated with Georg Friedrich Puchta, ${ }^{14}$ who argued for a conceptual formalism and the deduction of law from legal concepts. Possessed by the need to make law reflect the purity of intellectual logic, Puchta - as well as his student Rudolf von Jhering, in his earlier writings - understood legal science to be about the logical simplification of the law. ${ }^{15}$ This was to be achieved by the extraction, through abstraction, of legal concepts from legal rules and earlier writings; the scholarly chiselling of such concepts towards exactitude; and the formation of a logical and systematic ordering of concepts (what Jhering's close friend Bernhard Windsheid developed as a highly formal 'pyramid of

12 Exploring the contemporary importance of confidence for the traditions of international law and its relation to various therapeutic techniques, see Singh, Critique (n 8).

13 We both mirror and reflect on this medical trope in the hope of identifying some of the limits of existing forms of writing in scholarship. On the meaning of crisis as a medical trope see R. Koselleck, 'Crisis' (2006) 67 Journal of the History of Ideas 367.

14 See generally H-P. Haferkamp, 'Jurisprudence of Concepts' in S. Katz, The Oxford International Encyclopedia of Legal History (Oxford University Press 2009), 432-33.

15 The legal system was to be formed as the 'ultimate consequence of the scientific method'. See R. von Jhering, Der Geist des römischen Rechts auf den Stufen seiner Entwicklung (Scientia 1968) Part II section II (5th edn, [1858] 1898) 361. 
concepts'). ${ }^{16}$ For the early Jhering, 'concepts are productive, they mate and create new concepts', ${ }^{17}$ and their study belonged to a 'higher jurisprudence' ${ }^{18}$ Abstract, systematize, deduce. And repeat. This was about the 'creation of a world from purely intellectual matter' ${ }^{19}$

But conceptual abstraction and formal logic soon gave way 'in the face of the demands of life'. ${ }^{20}$ The commercial demands of modernization, the corresponding need for interpretive room in the application of the law, the slow fall from grace of systematic knowledge, all led Jhering towards a sociological jurisprudence. ${ }^{21}$ Though he maintained faith in a scientific approach to law, the philosophical foundations of this science were to change drastically. From formal logic and deduction there was a move to 'the scientific description of all experiences and facts which include the current high and final point of our knowledge and experience of law, organized for practical use'. ${ }^{22}$ On the one hand, this move towards life involved seeing law as a 'practical' activity, a 'concept of purpose' that was always living and being lived - for 'law is an eternal process of becoming'. ${ }^{23}$ It complemented his analysis of the instrumental character of law and how it served individual and social interests. ${ }^{24}$ On the other, even as he denounced pandectism, Jhering did not entirely abandon his dogmatism and abstraction of concepts. His critique targeted incorrect examples of deduction and overly theoretical attempts to construct concepts. But law was still composed of disembodied, manipulable and transformable legal concepts that ought to move towards, and still direct, social reality with the help of the purposes found in law and society. ${ }^{25}$

Wesley Hohfeld offers another sensibility. His seminal articles certainly adopt the aesthetics of nineteenth-century scholarship - a formal analytic method with a familiar systematic, almost mathematic, disposition ${ }^{26}$ - though Hohfeld's fundamental legal concepts were not merely atomistic substantive categories that needed to be made ever

16 See Binder's critique: J. Binder, Philosophie des Rechts (Stilke 1925) 439 et seq.

17 Jhering, Der Geist (n 15), Part I (5th edn, [1852] 1891), 40.

18 ibid 37-39.

19 R. von Jhering, 'Unsere Aufgabe' (1857) 1 Jahrbücher für die Dogmatik des heutigen römaischen und deutschen Privatrechts $1,12$.

20 Jhering wrote this to his friend Windsheid in 1965: see H. Ehrenberg (ed), Rudolf von Jhering an seine Freunde (Breitkopf \& Härtel 1913) 176.

21 It was a sociological jurisprudence that employed formalism in a critical manner. D. Kennedy, 'Legal Formalism' in N. Smelser and P. Baltes (eds), Encyclopedia of Social \& Behavioral Sciences (Elsevier 2001) 8635.

22 R. von Jhering, Ist die Jurisprudenz eine Wissenschaft. Jherings Wiener Antrittsvorlesung vom 16 Oktober 1868 (O. Behrends ed, Wallstein 1998) 92.

23 R. von Jhering, Der Kampf ums Recht (H. Klenner ed, Haufe [1872] 1992) 7, 9, 16. Jhering happened to experience the change when he saw the discrepancy between his abstract conceptual logic and the realities of practical reasoning in a case: see R. von Jhering, Scherz und Ernst in der Jurisprudenz (13th edn, Breitkopf \& Härtel [1884] 1924) 338.

24 R. von Jhering, Der Zweck im Recht, vol 2 (8th edn, Breitkopf \& Härtel [1877] 1924) 43 et seq.

25 R. von Jhering, 'Im Juristischen Begriffshimmel' in Scherz und Ernst (n 23), 245.

26 W. Hohfeld, 'Some Fundamental Legal Conceptions as Applied in Judicial Reasoning' (1913) 23 Yale Law Journal 16; 'Fundamental Legal Conceptions as Applied in Judicial Reasoning' (1917) 26 Yale Law Journal 710. 
more precise and well delimited in and of themselves. ${ }^{27}$ His concepts are, rather, forms that govern and may be used to govern a space of real legal relations, through their relations with correlating and opposing concepts. ${ }^{28}$ Hohfeld transformed how legal scholars see concepts and where to find them; perhaps above all, he reshaped how we ought to reason within the law. Concepts are not mere atomistic entities, but exist and take their meaning only through specific relations with others. But Hohfeld's project was never really about conceptual meaning. It is one that seeks to show that a given system of law and the real legal relations between individuals are each shaped by the conceptual distinctions and relations found in that system. Indeed, these 'deep' conceptual relations give law its 'fundamental unity and harmony', ${ }^{29}$ and law's conceptual economy ensures its systematic functioning has real distributive consequences in society. ${ }^{30}$ Furthermore, legal concepts no longer exist a priori to the life of the law. They and their relations are no longer ethereal entities made from the imaginations of legal philosophers. Rather, fundamental legal concepts are to be found in the law's application - for Hohfeld, this was in the judicial decision. ${ }^{31}$

Above all Hohfeld sought to grasp and distinguish the specifically legal aspect of his fundamental legal concepts. The 'tendency to confuse and blend non-legal and legal conceptions' was, for Hohfeld, based on two common reasoning errors. ${ }^{32}$ He wanted us to avoid conflating a legal concept with the mental and physical acts that bring it into being, as well as with its object. At its heart this was an exercise in purification. It was necessary to distinguish the social, economic and political aspects of a concept used in law from its legal aspects. Hohfeld argued that such a demarcation and delineation was often neglected, though wholly desirable and possible. Casting out all non-legal considerations from the world of law was intended, in turn, to purify legal concepts and our legal reasoning. Only in this manner could one pursue 'the correct solution of legal problems'. ${ }^{33}$ Despite his desire to master it, Hohfeld was intent on moving closer to the life of law. He offered a theory that allowed us to see legal concepts not as directives on what to think but as relations that show us how to think in the law. This was a diligent, though still highly restrained, unravelling of the restraints that concepts often impose on the legal imagination. In this manner Hohfeld sought to show lawyers how to better engage with the 'practical, every-day problems of the law'. ${ }^{34}$ And it was a project that would lay the foundations for both realist and critical legal scholars.

27 It seems clear that Hohfeld sought precision regarding the 'intrinsic meaning and scope' of his fundamental concepts, but this was a meaning and scope constantly shaped through relations with related concepts and not precision through definition: see 'Fundamental Legal Conceptions' 711; 'Some Fundamental Legal Conceptions' 58.

28 In disagreement with Hohfeld about a concept existing in relations and being spatial in nature, see A. Kocourek, Jural Relations (Bobbs-Merrill 1927) 234.

29 Hohfeld, 'Some Fundamental Legal Conceptions' (n 26) 59.

30 Hohfeld, 'Fundamental Legal Conceptions' (n 26) 747.

31 ibid 712; Hohfeld, 'Some Fundamental Legal Conceptions' (n 26) 58.

32 ibid 20-25. Pierre Schlag usefully talks of these as 'errors of transposition': see P. Schlag, 'How to Do Things with Hohfeld' (2015) 78 Law and Contemporary Problems 185, 192-200.

33 Hohfeld, 'Some Fundamental Legal Conceptions' (n 26) 19 (emphasis added).

34 ibid 20. 
Twentieth-century legal realists pushed our understanding of legal concepts and their role(s) in three further directions. The first such argument, no doubt building from Hohfeld, goes a little like this: Law's conceptual economy is in itself distributive of economic and political consequences in the social world. ${ }^{35}$ Alternatively: How we choose to draw, sustain and apply certain fundamental conceptual distinctions and relations has, in each and every variance, distinct economic and political implications. For instance, Hohfeld tells us that whether a landowner possesses a privilege or a right (parts of two of his fundamental conceptual relations) is 'a matter of great practical consequence and economic significance'. ${ }^{36}$ Though we don't always see this, our ground conceptual choices are anything but neutral. For the legal realist this may be explained by our failure to see and grasp a Hohfeldian lesson: law both and simultaneously permits as well as prohibits. If permission and prohibition are part of the same legal relation and lie at law's conceptual foundations, the lesson from the likes of Robert Hale and Duncan Kennedy is that we don't always see this as a single relation, and thus law as having a distributive effect, shaping real economic and institutional relations, when it allows a state of affairs to exist. We don't necessarily see these conceptual possibilities (as part of the same relation or) as part of the grounds of law, let alone see the rules associated with them as essentially contestable.

The Scandinavian legal realists pushed in a different, if familiar, direction. ${ }^{37}$ It was Alf Ross, most famously, who offered a furious, sustained and wide-ranging critique of international law's conceptual foundations. He showed how these foundations, as well as the dominant ways in which international lawyers thought about them, led into either metaphysical abstraction or logical error. For instance, his textbook was dedicated to showing the circular and contradictory conceptual relationship between law and sovereignty at the heart of the discipline. It was an egregious breach of formal logic, a 'disgrace', an 'obvious absurdity', and if a way out was sought it necessarily led to nothing more than a 'mystico-magical train of thought'. ${ }^{38}$ Ross saw conceptual

35 This first realist argument has been best developed by Robert Hale and Duncan Kennedy: see R. Hale, 'Coercion and Distribution in a Supposedly Non-Coercive State' (1923) 38 Political Science Quarterly 470; "Force and the State: A Comparison of "Political" and "Economic" Compulsion' (1935) 35 Columbia Law Review 149; Freedom through Law: Public Control of Private Governing Power (Columbia University Press 1952); D. Kennedy, 'The Stakes of Law, or Hale and Foucault' (1991) 15 Law Studies Forum 327, 333-34. The contemporary argument that international law has become central to contemporary inequality would be rejected by the legal realists on the count that with the proliferation of institutions, rules and the profession, the distributive impact of the law has merely become more visible.

36 Hohfeld, 'Fundamental Legal Conceptions' (n 26) 747 (though of course Hohfeld considers that there is only one correct choice between the applicability of these concepts); see also generally Schlag (n 32) 210-16.

37 The familiar names are of course Axel Hägerström, Anders Lundstedt, Karl Olivecrona and Alf Ross. For secondary literature providing a general overview, appreciation and response, see H. Hart, 'Scandinavian Realism' in Essays in Jurisprudence and Philosophy (Clarendon 1983) 161; M. Martin, Legal Realism: American and Scandinavian (Peter Lang 1997). See also A. Escorihuela, 'Alf Ross: Towards a Realist Critique and Reconstruction of International Law' (2003) 14 European Journal of International Law 703.

38 A. Ross, A Textbook of International Law: General Part (Longmans, Green 1947) 41, 41, 43 (respectively). 
circularity as depriving sovereignty of any content, or as 'unmeaning'. 39 Traditional jurisprudence was charged with attempting to escape this circularity by endowing sovereignty with independent meaning. Such an approach necessarily reified the complex social world that the concept was deployed to cover, not to mention its conflation of the ontological planes of law (or legal concepts) and fact, with the former often put in the position of directing the latter. It was in this sense that Ross's logical positivism pointed to international legal thought's deficiency in scientific logic and its descent into metaphysical abstraction. These tendencies could be explained by examining the link between international law's legality, the concept of sovereignty (and its 'unmeaning') and the 'emotional ideas of sublimity and sacredness of the power of the state'. ${ }^{40}$ Approached from Ross's perspective - legal science defined by the demands of philosophy ${ }^{41}$ - the legal concept of sovereignty was nothing more than 'ordinary nonsense', ${ }^{42}$ and ought to be disposed of.

Ross later expanded on this argument in a Harvard Law Review article that has become somewhat infamous. In it he put forward the case that some of those concepts which we consider to be crucial to a legal system might, upon discerning analysis, be disposable. Legal concepts such as 'rights' or 'ownership' were just as meaningless as the empty word 'tû-tû' so commonly used by 'primitive peoples'. Upon first sight, such concepts are usually considered indispensable and entirely filled with meaning. But Ross merely saw them as 'tool[s] of presentation'. ${ }^{43}$ When placed within legal rules such concepts merely hold together a series of 'conditioning facts', that is, a highly reified conception of social reality, and permit a 'systematic connection' to allow one to see the set of 'conditioned consequences' that would normally flow from the conditioning facts in any case. ${ }^{44}$ Or to put it otherwise, the functions assigned to such concepts in a legal system were wholly unnecessary. This was especially the case given Ross's demand that legal science pursue the task of 'systematic simplification' 45 (much akin to the ethos of Hohfeld), leading him to the conclusion that all that was superfluous ought to be disposed of. Indeed, the reality of a legal system could be better described and understood without the need to have recourse to such concepts. Resort to them arguably distorts and distracts us from a more realistic understanding of how the law operates. ${ }^{46}$ Legal concepts such as sovereignty or rights then 'bear a considerable structural

\footnotetext{
39 ibid 12.

40 ibid 112.

41 Martin (n 37) 123-26; A. Ross, Directives and Norms (B. Loar ed, Routledge 1968).

42 Ross, Textbook (n 38) 34.

43 A. Ross, 'Tû-Tû' (1957) 70 Harvard Law Review 812, 820.

44 ibid. It is important to bear in mind that Ross is susceptible to the critique that he conflated concepts with legal rules, without fully understanding or elaborating on their distinction and distinctive roles: see D. von der Pfordten, 'About Concepts in Law' in J. Hage and D. von der Pfordten (eds), Concepts in Law (Springer 2009) 17, 32.

45 Ross, 'Tû-Tû' (n 43) 821; see also 819-22.

46 A. Ross, On Law and Justice (University of California Press 1959) 19.
} 
resemblance to primitive magic' ${ }^{47}$ And magic, like all metaphysics, must be dispelled by force of logic.

Ross's critique went to the very heart of the discipline; it was both fundamental and immanent. Scientific enlightenment was pursued so that law could stand on firmer ground and be able to better defend itself against critiques of the time. For Ross, "the most effective way to vanquish metaphysics in law is simply to create a scientific theory of law whose self-sufficiency will push metaphysical speculations into oblivion along with other myths and legends of the childhood of civilization' ${ }^{48}$ No doubt he put too much faith in the possibilities of science and theory. International lawyers would continue to take recourse to the concepts he targeted despite, and arguably because of, their 'structural petrification' 49 and emotional importance. The practice of law - its doctrines, its argumentative structures and its institutions - also remained largely, if not wholly, unaffected. ${ }^{50}$ Yet Ross imparts enduring lessons. The conceptual resources of the discipline could never be reduced to an assigned scientific role, nor could they be purged through the force of logic; it seems that international law's conceptual structures are both a source of its weakness and its durability; these concepts were inherently fragile and could be easily dismantled; and because of their apparent centrality they do not deserve our blind adherence, but rather far more discerning modes of demystification (at least, more discerning than those put forward by Ross). And magic, it seems, has continued to shape the international legal world.

The third enduring strand of realism's legacy is best exemplified by the work of Felix Cohen. His well-known article Transcendental Nonsense, in the midst of its scathing critique of Jhering's 'heaven of legal concepts', ${ }^{51}$ raises three points of note. Addressing the apparently legal concept of a corporation in a judgment written by Judge Cardozo, Cohen took Hohfeld's lesson several steps further. In his view the court had conflated the social and object properties of a corporation with the legal characteristics of the concept. The former was read into and fully defined the latter. The problem for the Court and for Cohen, is that a strictly legal conception of a corporation does not exist. "But this does not give us the right to hypostatize, to "thingify," the corporation.' 52 Cohen's first objection is that in doing so we remove from our conscious

47 Ross, 'Tû-Tû' (n 43) 818. Ross extended his analysis to the concept of law in A. Ross, Towards a Realistic Jurisprudence: A Criticism of Dualism in Law (A. Fausbøll tr, E. Munksgaard 1946) 20.

48 Ross, On Law (n 46) 258. In his defence of and commitment to the discipline, Ross held critiques of both legal formalism (and its conceptualism - a point he shared with American legal realists) and contemporary forms of natural law emerging from political realism. Obviously here we have focused on the former. For an excellent analysis, see Escorihuela (n 37) 736-59.

49 Ross, 'Tû-Tû' (n 43) 223.

50 On the effect of legal realist thought on the profession see the useful contrasting perspectives of Koskenniemi and Singer, even though the former focuses on Ross and international law and the latter on the American vein. See, M. Koskenniemi, 'Introduction: Alf Ross and Life beyond Realism' (2003) 14 European Journal of International Law 653; J. Singer, 'Legal Realism Now' (1988) 76 California Law Review 465.

51 F. Cohen, 'Transcendental Nonsense and the Functional Approach' (1935) 35 Columbia Law Review 809, 811.

52 ibid 811. 
consideration and legal reasoning the important 'economic, sociological, political, or ethical questions' 53 involved in making a corporation a legal concept and understanding it as such. Note that the argument is emphatically not that the legal concept of a corporation is to be determined by the economic, sociological or political properties of the entity. It is precisely the opposite. It is rather that in order to reach a specifically legal conception and to answer a specifically and properly legal question, we have to engage with the economic, social and political elements and realities of a concept. Law must move towards social life even if it must also receive it on its own terms - though curiously, in Cohen's text we can also observe that the desire to demarcate the specifically legal (of a concept) is marked by the persistent and readily apparent difficulty (if not impossibility) of the task. ${ }^{54}$ At the heart of Cohen's second objection is the knowledge that this tension does not however relieve the lawyer or scholar of his or her ethical obligations.

If concepts do not arrive from Jhering's heaven, but are made and remade in judicial decisions ${ }^{55}$ if legal concepts simultaneously shape and are shaped by the social world beyond the law; ${ }^{56}$ and if we are to ask and answer specifically legal questions, ${ }^{57}$ then we can no longer defer or assign the 'moral responsibility' of our legal decisions and our conceptual economy to the 'ghost-world of supernatural legal entities'. ${ }^{58}$ For Cohen concepts are constructs that serve certain functions and may be put to certain uses. In a given context, our choice of this or that function and this or that meaning or conceptual relation necessarily shapes the world in a certain way. So the question of whether we should make each of the determinations in the manner and purpose we do "is inescapably an ethical question'. ${ }^{59}$ In turn research must engage with this. It must necessarily 'look behind' our determination of a legal concept, to 'appraise in ethical terms the social values at stake' and to 'map the hidden springs of judicial decision' ${ }^{60}$ This project would no doubt benefit from the insights of anthropology, psychoanalysis, sociology, social psychology, economics and a range of other social sciences.

A final point regarding Cohen's text remains. It should now be apparent that his pragmatism sits in stark contrast to Ross's philosophical-scientific logic. Where the latter sought to banish meaningless concepts from legal reasoning, the former saw it as our task to 'salvage' them and to redefine them as 'functions of actual experience'. ${ }^{61}$ Where Ross saw law as a science, Cohen saw it as a practice. And yet throughout their work there was a structural similarity. Cohen understood that the power of concepts

\footnotetext{
53 ibid 810.

54 For an illuminating analysis, see Schlag (n 32) 231-33 (showing how Cohen ends up almost abandoning the legal aspect of the concept of corporation in his search for it); P. Schlag, 'The Dedifferentiation Problem' (2009) 41 Continental Philosophy Review 35 (arguing that it may indeed be impossible to properly make the distinction).

55 Cohen (n 51) 827-28.

56 ibid 815-17.

57 ibid 823-24.

58 ibid 828.

59 ibid 840.

60 ibid 833.

61 ibid 827.
} 
could lie in their mythical quality and yet his functionalism sought to reduce them to social facts. Or, in his words, 'myths may impress the imagination and memory where more exact discourse would leave minds cold', ${ }^{62}$ and yet his article established itself on the demand that 'concepts which cannot be defined in terms of experience ... any word that cannot pay up in the currency of fact, upon demand, is to be declared bankrupt and we are to have no further dealings with it' ${ }^{63}$ Where Ross's work on concepts operated within a structure of magic and logic, firmly resolved in favour of the latter, Cohen's operated between myth and fact. Despite ultimately finding in favour of fact, Cohen's text is a step forward in that it allows us to see the anxious ambiguity that operates in this structure: myth and fact differ in degree and not in kind. ${ }^{64}$

As shown in the short overview provided in the previous pages, how we tend to think about the nature of legal concepts was clearly pushed into different, and at times conflicting, directions by the early legal realists. Each strand and its peculiar dynamics found later roots in the work of New Haven, legal process, law and economics and new legal realist scholars, ${ }^{65}$ although it is far from clear that these approaches offer anything fundamentally new in how we think of legal concepts. Perhaps more to the point the anti-conceptualism of these realist strands was undermined by their reliance on the very types of abstract or formal concepts that they had just critiqued as formalistic nonsense. When taken too far, these social scientific tendencies spawned the belief that the social outcomes of the law and its conceptual economy could be reduced to debatable facts. ${ }^{66}$ Take the concepts of 'efficiency' or 'compliance' or 'transaction costs' that are

62 ibid 812.

63 ibid 823.

64 Even empiricists grasped this. Gods and physical objects were seen as operating on the same epistemological footing: see W. Quine, From a Logical Point of View (Harvard University Press 1980) 20.

65 Before the New Haven school, there were several anticonceptualist realist works in international law: see G. Williams, 'International Law and the Controversy Concerning the Word "Law"' (1945) 22 British Yearbook of International Law 146. McDougal and Lasswell took up the turn to the social sciences, the complementary and opposing relations in which we encounter legal concepts, the need to empirically ground abstract concepts and the teleological use of the normativity of legal concepts. See M. McDougal and H. Lasswell, 'Criteria for a Theory about Law' (1970-71) 44 Southern California Law Review 362, 384; H. Lasswell and M. McDougal, Jurisprudence for a Free Society: Studies in Law, Science and Policy (Nijhoff 1992). Law and economics, legal process and new legal realist scholars all seem to take up the empiricism and pragmatism offered by Cohen and many of his colleagues. Legal concepts take their meaning by recourse to policy, economic and social considerations, and these scholars focus on how these 'analytic priors' seem to work. Such concepts also have a processional aspect in the sense they are revisable in light of empirical experience. See Singer (n 50) (for an excellent overview of law and economics approaches to concepts and their relationship with earlier legal realists); J. Goldsmith and E. Posner, The Limits of International Law (Oxford University Press 2005) (exposing the interests behind certain legal concepts); A. Guzman, How International Law Works: A Rational Choice Perspective (Oxford University Press 2008); G. Schaffer, 'The New Legal Realist Approach to International Law' (2015) 28 Leiden Journal of International Law 189, 199-204 (on each of the above themes and the links between these schools).

66 Note that it is precisely this problem and the anxiety that arrives with it to which Cohen, perhaps more so than Hale, alluded. See the main text relating to notes 61-64 of this chapter. 
the foundation of law and economics scholarship, for example. ${ }^{67}$ One realist lesson was learnt while others were conveniently forgotten. The abstract was readily turned into a constructed and manmade social fact relatable to actual experience. Yet two points were marginalized, if not entirely elided. The first is how these constructed social facts were often subtly dependent on abstract and apparently neutral concepts. The ethical obligation, advanced by legal realists, to be transparent about and debate the political values and choices that one makes and advances is all but side-lined in this move. Second, the focus on measurable social outcomes often ignores the realist's ability to understand that law's normativity came as much from its 'magic' as from its standing as social fact. These realist lessons, both applied and unlearnt, continue to animate many of the debates in contemporary international law. 'Compliance', 'efficiency', 'regimes', 'legitimacy' are just some concepts that have been susceptible to the aforementioned critiques, and each pertains to how we see - that is, our conception of - international law. ${ }^{68}$ These critiques largely emerged with the work of critical scholars.

More to the point, critical scholarship offered novel ways of thinking about the nature and role of concepts in international law. Unfortunately considerations of space mean we are only able to focus here on the critical strand of international legal structuralism, and are unable to explore the unique contributions of ideology critique, different Marxist approaches and aspects of postcolonial scholarship.

As is well known, David Kennedy and Martti Koskenniemi were at the forefront of the structuralist enterprise. In different ways, but with a common 'internal' approach, both scholars sought to show that international law's strength - that is, its systematic coherence, its stability and its relevance - lay in its structural indeterminacy. Koskenniemi's project sought to show how international lawyers' arguments about and with key concepts such as sovereignty or obligation (even as they were called 'discursive topics' or doctrines) rested upon 'an underlying set of assumptions', which could be expressed in fundamental conceptual oppositions (public/private, binding/nonbinding, rules/standards, naturalism/positivism). ${ }^{69}$ These key concepts, to which others such as

67 D. Kennedy, 'Distributive and Paternalistic Motives in Contract and Tort Law, with Special Reference to Compulsory Terms and Unequal Bargaining Power' (1982) 41 Maryland Law Review 563, 603 (showing the point in relation to efficiency); Singer (n 50) 522-28 (showing this in relation to law and economics scholarship in the United States, though much of the same critiques emerged 20 years later in international legal scholarship).

68 Offering these critiques, and reminding us of forgotten legal realist lessons, in various forms are B. Kingsbury, 'The Concept of Compliance as a Function of Competing Conceptions of International Law' (1998) 19 Michigan Journal of International Law 345; M. Koskenniemi, 'The Fate of Public International Law: Between Technique and Politics' (2007) 70 Modern Law Review 1; M. Koskenniemi, 'Law, Teleology and International Relations: An Essay in Counterdisciplinarity' (2012) 26 International Relations 3. On 'compliance' see the chapter by Ingrid Wuerth, on 'effectiveness' see the chapter by Gleider Hernandez and on 'legitimacy' see the chapter by Oliver Kessler and Filipe Dos Reis, all in this volume.

69 M. Koskenniemi, From Apology to Utopia: The Structure of International Legal Argument (reissue with new epilogue, Cambridge University Press 2005) 7-9. Kennedy's work differs in that he sought to look at how the discursive fields of sources, process and substance ultimately slid into each other (and how this process was managed/hidden/displaced and manipulated), as well as how different fundamental conceptual oppositions structured these 
legitimacy, authority or the state could be included, were important precisely because of their semantic emptiness, because lawyers constantly took recourse to them, because they are key entry points for an analysis of the discipline and because they were the joints and hooks for multiple ways of arguing within international law. Koskenniemi sought to understand 'what rules govern the production of arguments ... and why it is that no definite resolution of standard problems has been attained'.$^{70}$ With regard to the first concern, Koskenniemi argued that international legal arguments and positions were ultimately dependent on a 'system of conceptual differentiations',${ }^{71}$ operating at various levels of abstraction (such as state/community, consent/justice, concreteness/ normativity, apology/utopia or idealism/realism). In these conceptual oppositions each individual concept is merely an empty form that only takes up meaning through its formal difference and differentiated relation with its opposing concept. International lawyers often seek to approach a legal argument by implicitly prioritizing one concept over the other, only to realize that they are susceptible to a persuasive critique from an argument that rests on the opposing concept. It becomes logically impossible to elevate one contradictory concept above the other because each depends on the other. They exist together, and always in a differentiated relation. For Koskenniemi this conceptual economy comprises international law's grammar; it sits in its background, entirely assumed, defining 'the conditions of what can acceptably be said within [international law], or what it is possible to think or believe in it'. ${ }^{72}$ This conceptual system takes its historical cues from the antinomies of political liberalism, defines the liberal project of international law (not to mention its main categories, concepts and ideas) and above all shapes the social identity of the international lawyer.

In the midst of this no doubt familiar picture, we can draw out four particular lessons on the nature and roles of concepts in international law. First, international legal concepts are not 'discursive monuments', ${ }^{73}$ or achievements to be better attained, as Aristotle or Kant might have us believe. Sovereignty, state, authority, democracy or legitimacy, to name a few, are each irreducibly normative propositions. They are

fields (most notably hard/soft, consent/justice, objectivity/subjectivity, sovereign autonomy/ international cooperation): see D. Kennedy, 'Theses about International Law Discourse' (1980) 23 German Yearbook of International Law 353; International Legal Structures (Nomos 1987) 290. From a philosophical perspective there is a Hegelian move here. Hegel argued that concepts encompass both the particular and the universal, and that concepts are only forms, becoming determinate when related to a predicate. We can only grasp all the particular determinations, ie the concrete universal totality, of a concept (eg sovereignty or obligation) by a double movement of the dialectic (upwards and downwards). Through the process of disjunctive judgment the concept is attached to its necessary predicates (in structuralism, these are the fundamental conceptual oppositions). In this manner could one bring about the progressive enhancement of the concept and its content and move towards the ethical life (this was what he saw as the potential of the concrete universal): see G.W.F. Hegel, Hegel's Science of Logic (A. Miller tr, Humanities Press International 1969) 60.

70 Koskenniemi, Apology to Utopia (n 69) 8 (original emphasis). This approach parallels a major influence on Koskenniemi: see M. Foucault, The Archaeology of Knowledge (A. Sheridan Smith tr, Routledge 2002) 38.

71 Koskenniemi, Apology to Utopia (n 69) 10 (original emphasis).

72 ibid 11 (original emphasis). See also Foucault, Archaeology of Knowledge (n 70) 127-32.

73 Foucault (n 70) 153. 
founded on 'crumbling soil', ${ }^{74}$ wholly heterogeneous terrains on and through which there are various conflicting (but ultimately predictable and coherent) argumentative strategies; they are structurally indeterminate. In Foucauldian terms, these concepts are forms that offer continuous discontinuity. Structuralism not only tears away the apparent self-evidence of concepts, but also shows us that their import and coherence comes from certain discursive rules that govern their making, circulation and transformation. Theirs is not an indeterminacy that can be resolved by speaking the same language or ensuring consistency of meaning or the correction of cultural and interpretive differences. ${ }^{75}$ They, and international legal discourse, are indeterminate at their core. And their virtue lies in precisely this quality.

Second, concepts occupy the 'middle' of social life. This is true in a double sense. Concepts are both the instruments and the objects of structuralist research. They offer a route into the analysis of legal discourse, and an analysis of their 'incompatibility', as well the 'interplay of their appearances and dispersion', offers us the ability to simultaneously grasp the deep-structural unity of international legal discourse and transform it and its key concepts. ${ }^{76}$ In another sense, concepts arrive in the broken middle of social life due to a hermeneutic sensibility. We, as international lawyers, cannot refuse to use, or ignore or discard (with a wink and nod to Ross), the concepts of international law. They are inescapable precisely because they represent the historical conditions of possibility for international law and international legal life. ${ }^{77}$ At a rudimentary level, Koskenniemi shares with analytical jurisprudence and realists such as Cohen the belief that language is prior to thought; our concepts are pre-rational. ${ }^{78}$ But Koskenniemi's argument goes further. Sure, concepts and conceptual schemes allow us to see the international legal world, to orient ourselves within it and to know it. ${ }^{79}$ But they are not imposed by method or by scholars. They are the products of a history made by international lawyers, or products of social life, and they are inherited

74 ibid

75 Koskenniemi, Apology to Utopia (n 69) 61-63.

76 Foucault, Archaeology of Knowledge (n 70) 38-39; see also Koskenniemi (n 69) 12-13.

77 ibid xiii, $11-12$.

78 ibid 12; Cohen (n 51) 812; A. Marmor, 'Farewell to Conceptual Analysis (in Jurisprudence)' in W. Waluchow and S. Sciaraffa (eds), Philosophical Foundations of the Nature of Law (Oxford University Press 2013) 209, 210-12.

79 Analytic philosophy and its progeny in legal thought (ie positivism and aspects of legal realism) separate the empirical world and our concepts. They may be mutually dependent and influence each other, but they are separate. This has led to a species of philosophy that sees its task as one of 'conceptual elucidation ... a kind of reflective conceptual self-consciousness'. See 'Peter Strawson' in A. Pyle, Key Philosophers in Conversation: The Cogito Interviews (Routledge 1999) 36, 38. The predominant view is that conceptual work helps sharpen empirical analysis, which in turn can reshape conceptual categories: see 'Hilary Putnam' in ibid 44, 49 and 'Stephan Körner' in ibid 55, 56, 62; this perspective is predominant in contemporary new legal realist work: see Schaffer (n 65) 200. See the main text relating to the fourth point to consider how this view differs from concepts and life being mutually mediating (rather than dependent, constitutive and so on). It is similar to, if not aligned with, the view presented by MacIntyre: see 'Alistair MacIntyre' in Pyle 75, 78. 
and internalized to mediate our contemporaneous relationship with the international legal world (see further point 4 below). And further: precisely because we cannot do without them, we are also liable to be misled by them. ${ }^{80}$

Third, international legal concepts cannot be reduced to the functions for which they are put to use. ${ }^{81}$ Though the premise for Koskenniemi's argument is that law is irreducible to instrumental desires or interests, this is also an observation that intimates a novel understanding about the nature of concepts and implies a certain conceptual performance. In this respect, concepts are plagued with two inevitable excesses. The first is the inevitable excess of the object: when we use the concept 'state', the linguistic use can never capture the complexity and 'thingness' of its 'object'. ${ }^{82}$ The second is the indeterminate excess of meaning: signifier (or expression) can never be captured by the signified (meaning) - as Derrida might say, a 'dangerous supplement' will always be produced. ${ }^{83}$ How a conceptual performance attempts to deal with these excesses tells us a great deal about it. Koskenniemi's deconstructive structuralism, for example, grapples with each of these excesses and seeks to absorb (rather than overcome) them.

Fourth, conceptual schemes are indissociable from the life of the law and how international lawyers live. Because Koskenniemi only brushes the surface of this point, we delve into the subtleties of his text and move beyond it so as to grasp the scope and importance of the issue. Koskenniemi was able to show how the unity, or, better yet, coherence of international law came from understanding that its order was premised on tensions and contradictions. His deconstructive structuralism infamously introduced the much misunderstood indeterminacy thesis. It offers movement: the ebbs and flows of international legal argument; an understanding of how it pivoted around assumed dialectical concepts, and how contradictory and mutually dependent patterns of justification could be traced to these assumptions. ${ }^{84}$ Common readings of structuralism only see it as a form of knowledge that enables a specific form of praxis. It is seen as a way of knowing, or rather a redefinition of knowing, international law; a sspace in which the [international lawyer] may take up a position and speak of the objects with which he deals in [international legal] discourse', or one defined by 'the possibilities of use and appropriation' of the conceptual schema offered by the discourse. ${ }^{85}$ Professional competence is then measured by a lawyer's ability to handle the indeterminacy of international law, to grasp this conceptual schema and to show an ability to move or

80 Koskenniemi, Apology to Utopia (n 69) 11-12 (relying on Horkheimer for the historical and social making of concepts and categories which are to be analysed and used for analysis, and relying on Lévi-Strauss for the ideological aspect of "conceptual schemes which are taken as objective categories').

81 ibid 67 (they possess 'a degree of autonomy' that must be accounted for in the law).

82 ibid; see also T. Adorno, Negative Dialectics (E. Ashton tr, Routledge 1973) 5 ('the concept does not exhaust the thing conceived').

83 Koskenniemi, Apology to Utopia (n 69) 9 at fn 6 (with reference to Derrida's Of Grammatology). See also ibid 10 at fn 8.

84 See for a good summary ibid 58-69.

85 Foucault, Archaeology of Knowledge (n 70) 201. See also Koskenniemi, Apology to Utopia (n 69) 73 (main text and fn 6). 
orient oneself within it. ${ }^{86}$ Above all, this form of knowledge is both enabling and constraining. The dynamic terrain of international law is now seen as opening up 'strategic possibilities' for the lawyer. ${ }^{87}$

The world of international law opened up by Koskenniemi's approach to its concepts and conceptual schema is not only concerned with knowledge and strategic action. It is a 'therapeutic' 88 epistemology guided by an ethics. It is about living. ${ }^{89}$ Or, more precisely, it is, as Foucault's structuralist work made clear, about understanding and prioritizing 'the concept of the living' as a novel way of 'approaching the notion of life.' ${ }^{90}$ As Foucault put it:

The fact that man lives in a conceptually structured environment does not prove that he has turned away from life, or that a historical drama has separated him from it - just that he lives in a certain way, that he has a relationship with his environment such that he had no set point of view towards it, that he is mobile on an undefined or rather broadly defined territory, that he has to move around in order to gather information, that he has to move things relative to one another in order to make them useful. Forming concepts is a way of living and not a way to immobilize life; it is a way to live in a relative mobility and not a way to immobilize life. ${ }^{91}$

Foucault recasts the relation between concepts, knowledge and living. With the help of hermeneutics (notably Heidegger), we may push this point. ${ }^{92}$ The concepts and conceptual worlds of international law allow us to live in its indeterminate structures both before and as it becomes known to us. These conceptual worlds are prereflectively disclosed to us through international law's pre-existing concepts and categories, and only then are these worlds reflectively disclosed through us. ${ }^{93}$ The social world of international law, its concepts and our identities as international lawyers are all simultaneously implicated and indissociable. Or: we live in international law through its concepts and categories before we come to know it and as we come to know it; we can only come to know the social reality of international law through our own identity as international lawyers and our ability to grapple with its concepts and

86 ibid 11, 73. For further observations, see S. Singh, 'The Critic(-al Subject)' in W. Werner, M. de Hoon and A. Galán, The Law of International Lawyers: Reading Martti Koskenniemi (Cambridge University Press 2017) 197.

87 Prost (n 6) 154; see also Koskenniemi, Apology to Utopia (n 69) 73; Foucault, Archaeology of Knowledge (n 70) 220-21.

88 Koskenniemi, Apology to Utopia (n 69) 13.

89 ibid 548 ('The problem is what the lawyer should do in an inherently conflictual reality of international life ... the problem of international law is ... whether and how one can live in and through it' (original emphasis)). Unfortunately, Koskenniemi does not expand on this concept of living any further.

90 M. Foucault, 'Life: Experience and Science' in Aesthetics, Method, and Epistemology: Essential Works of Foucault 1954-1984, vol II (J. Faubion ed, R. Hurley and others tr, New Press 1998) 465, 477.

91 ibid 475.

92 There is a strong link to the second point explored in relation to Koskenniemi's text: see the main text and accompanying footnotes 76-80 above.

93 Koskenniemi, Apology to Utopia (n 69) 12, 548; M. Heidegger, The Basic Problems of Phenomenology (A. Hofstadter tr, Indiana University Press 1988) 169-70. 
categories; and finally, to live, or dwell, within the law means living imaginatively within its dynamic conceptual (or, more broadly, linguistic) structures. ${ }^{94}$ This calls for an observation.

How we traditionally conceive of concepts is turned on its head. We live with and through legal concepts before we can know, do or make anything with them. ${ }^{95}$ Inversely, seminal works in adjacent fields primarily consider concepts as vehicles for action and as constitutive of social beliefs, practices and reality. ${ }^{96}$ Pushing us in important and admirable directions, these works see concepts as the result of manmade activity, as moral-ideological battlegrounds where and through which various projects and agendas are pushed and suppressed, and as weapons to be used in political struggle. These works ably trace the mechanisms and mechanics of power in these concepts. But these strains of scholarship prioritize the epistemological above the ethical, even as they attempt to hold both strands together. Such is the search for knowledge and its interstices with power that we forget the intimate relation between dwelling and our concepts. If, as Heidegger would have it, living is prior to doing or making, international lawyers 'must ever learn to dwell' ${ }^{97}$ In one sense this means we must make sense of ourselves in a given world just as we seek to make sense of this world; our very identity as international lawyers (and often our selfhood) is implicated by international law's concepts. In another sense, this means that, alongside questioning our concepts and their complicities with power, we realize that they are not easily transformed or displaced, that we cannot take flight from them so easily and that above all we must, in various ways, preserve, care for and cultivate them. ${ }^{98}$ Doing so in the full understanding that they offer a perilous terrain.

94 Koskenniemi, Apology to Utopia (n 69) 548-61; M. Heidegger, ‘... Poetically Man Dwells ...' in M. Heidegger, Poetry, Language, Thought (A. Hofstadter tr, Harper \& Row 1971) 211; Foucault, 'Life' (n 90) 470 (all on the retained link between imagination and knowledge); see also J. White, The Legal Imagination (University of Chicago Press 1973), 71 ('He is less defined by the language he uses than by his relationship with it that he can establish and maintain, less by his material than by art').

95 Or in Heideggarian terms we $d$ well (and dwelling is not something we $d o$, or is not purely an activity) before we build or think, even if both are essential to dwelling: 'Only if we are capable of dwelling, only then can we build.' M. Heidegger, 'Building Dwelling Thinking' in Heidegger, Poetry, Language, Thought (n 94) 143, 157 (original emphasis).

96 On the relationship between concepts and action, see Q. Skinner, Visions of Politics. Volume I: Regarding Method (Cambridge University Press 2002), 145-87; Lara (n 3); S. Guzzini, 'The Concept of Power: A Constructivist Analysis' (2005) 33 Millennium: Journal of International Studies 495. On understanding concepts as part of a constitutive activity and constituting fields, see R. Williams, Marxism and Literature (Oxford University Press 1977) 21-44 (also speaking to the individual's preconstitution in language, but this misses the hermeneutic point of disclosure - our identity appears through and is indissociable from our concepts and language); 'Preface' in T. Ball, J. Farr and R. Hanson, Political Innovation and Conceptual Change (Cambridge University Press 1989) ix; 'Editor's Introduction' in ibid 1; Q. Skinner, 'Language and Political Change' in ibid 6; J. Farr, 'Understanding Conceptual Change Politically' in ibid 24; H. White, 'Foreword' in R. Koselleck, The Practice of Conceptual History: Timing History, Spacing Concepts (Stanford University Press 2002) ix.

97 Heidegger, 'Building Dwelling Thinking' (n 95) 159 (original emphasis).

98 ibid 145. 
Critical scholarship has undoubtedly pushed in different directions and we have no room here to explore each of them. But it seems almost inevitable - reading Koskenniemi or Marx on political economy, Adorno on philosophical thought, Marcuse on social thought or Geuss on political thought - that the conceptual worlds that we inherit and that shape our prior (or pre-reflective) understanding of international law will incorporate hidden traces of power and domination. What are we to do if our image of international law is pre-reflectively disclosed to us through reified concepts and categories?99 Indeed, what are we to do if how we think through these concepts is reified? ${ }^{100}$ How are we to possess and live with concepts such as rights, law, justice or humanity when they possess us in such an intimate manner? Critical theory teaches us that our reflective disclosure of the conceptual worlds of international law may decentre and transform our 'false' prior understanding of the world. For example, critical scholarship has excelled at tracking the concrete universal, or rather the particular in the universal, or the hidden paths of power and domination in our cherished concepts. It has seen these concepts as channelling power as living abstractions - to be found in our symbols, discourses, institutions, practices or forms of consciousness - wherever power resides. This critical work pushes us against essentialist assumptions about concepts and marks them with their historicity, contestability and contingency. Scholars have been able to transform how we see these assumptions and called into question our desire to preserve them, as well as opening up possibilities of acting differently. ${ }^{101}$ And finally, in rare instances this scholarship brings patterns of domination to the fore while also urging the critical demand that international law lives up to the demands of its concepts, pointing us towards how it can be made more humane, or democratic, or equal. ${ }^{102}$

Despite our promise, this section scarcely outlines any history, let alone one of progress or refinement. It may be more accurate to say that it has taken a theoretical approach to the historical sensibilities of lawyers. We sought to emphasize the nuances, fissures and tensions that seem to define and structure their approach to legal concepts. Each of the authors explored in this section were chosen because their sensibilities seemed to find an echo in contemporary voices that reside in the various silos of international legal culture. Just think of the fetish for conceptual description and

99 See the main text accompanying n 93 of this chapter.

100 This subtly different question was asked by Adorno: see Adorno (n 82); G. Rose, 'How Is Critical Theory Possible? Theodor W. Adorno and Concept Formation in Sociology' (1976) 24 Political Studies 69.

101 See eg D. Chakrabarty, Provincializing Europe: Postcolonial Thought and Historical Difference (Princeton University Press 2000) (on concepts of European modernity); Anghie (n 5) (on sovereignty); Pahuja (n 5) (on development); M. Koskenniemi, 'Sovereignty, Property and Empire: Early Modern English Contexts' (2017) 18 Theoretical Inquiries in Law 355; A. Çubukçu, 'Thinking against Humanity' (2017) 5 London Review of International Law 251.

102 The best exponent of this kind of critique is Susan Marks: see S. Marks, The Riddle of All Constitutions: International Law, Democracy, and the Critique of Ideology (Oxford University Press 2000); S. Marks, 'Introduction' in Marks (n 5), International Law on the Left 1. See also Koskenniemi, 'Law, Teleology and International Relations' (n 68) (with regard to progress). This type of critique may also be found in the influential line of critique seen in Adorno's nonidentity thinking: see references in n 100. 
precision with little concern for international life, or the normatively ambiguous reduction of this legal life to certain outcomes, or the fascination with the distributive consequences of law's conceptual economy, or the vicissitudes of power that accompany legal concepts. ${ }^{103}$

These sensibilities are, then, in large part important for understanding the breadth and depth of the cultural resources that our shared intellectual history provides. We have proceeded thus far on the understanding that this section has drawn images of various legal sensibilities in our approach to legal concepts. In fact, we have drawn attention to the specifically aesthetic, political and ethical aspects of written works by various scholars. Our argument may be put succinctly: How we today live in, see, understand, think about and know international law through its concepts has been constantly reoriented and transformed on the shifting and entwined terrains of aesthetics, politics and ethics. Each terrain not only moulds the work of the various scholars, but also shapes our contemporary sensibilities (in their living, seeing, understanding, reflectively thinking and knowing). And no doubt the aesthetic, political and ethical elements of the above texts can be grasped at the interstices of our above textual readings. But we would like to sketch briefly - and perhaps in a manner tending towards caricature - the shifting sands of these three elements in each of the various legal sensibilities explored above.

First, aesthetics. Aesthetics are those forms, images and perceptions that shape our legal sensibilities. Take for starters the aesthetic properties assigned to the appearance of legal concepts. In the work of Puchta or that of early Jhering, concepts were conceived of as solid, highly specific and well-defined entities (not much unlike a lot of definitional discourse today), that seemed to work as part of a systematic order. In Hohfeld their edges began to blur, before later realists such as Cohen could no longer sustain the boundaries between legal, political or economic aspects of concepts; critical sensibilities lacked any confidence in the solidity of a concept's internal and external boundaries, as well in the ability to grasp it in the singular, and so concepts were grasped through their discontinuities, their incompatibilities and the instability of their boundaries. ${ }^{104}$ Unsurprisingly, these each correspond to an aesthetic of location, that is, where scholars tend to find and direct legal concepts - first they appear as a priori to social life, then ex-post, and finally in the life's 'broken middle', 105 that place that

103 The premise of this approach is that how lawyers have approached legal concepts cannot be told as a history of revolution or 'paradigm shifts', where we are persuaded to think that our legal science has been advanced steadily by the incremental collection and displacement of knowledge regarding legal concepts - first by the realists upon the conceptualist, then by the critical scholars on the realists and formalists. This would of course be a gross misunderstanding of how international legal culture accumulates and uses knowledge. This also does not mean that certain approaches at particular times are considered more en vogue, nor does it mean that our historical sensibilities are not infused with a sense of movement, of agitation. For an understanding why the Kuhnian approach may be wholly unsuitable, theoretically or historically, for the legal culture and legal thought, see P. Kahn, The Cultural Study of Law: Reconstructing Legal Scholarship (University of Chicago Press 1999).

104 See eg Pahuja (n 5) 25-43 (exploring the critical instability of international law's boundaries and being the starting point of analysis).

105 G. Rose, The Broken Middle (Blackwell 1992). 
provides both anxiety and movement. We are often drawn to, and continue to unwittingly ply, these aesthetics over and over again, and at the sociohistorical juncture at which they become consciously resorted to, a particular fetish develops in our disciplinary silos - scholarly work (on legal concept and even law tout court) is expected to abide by a given and accepted aesthetic.

Equally inescapable in our contemporary sensibilities regarding legal concepts is their shifting relations to politics. For present purposes we may understand politics as an intimate relation to power. Historically pandectism was marked by a failure to grasp any relationship between legal concepts and power, though fastforward a century and this sensibility had quickly evolved into an understanding of this relationship as a highly complex one in which the responsibilities of the lawyer are constantly implicated. Jhering's concepts knew no direct relation to power or the political; they descended from 'heaven', recused themselves from the world and took up residence in the logical technicalities of theory. Hohfeld, Hale and Cohen changed all this when they showed us how law's conceptual economy was directly related to its economic and social distributive consequences. They realized not only that law's conceptual economy could be distributively unjust, but also that its very structure could (in a simple sense) allow it to be otherwise. Legal concepts and power became co-conspirators and power came to be seen as multidirectional. Some years later, Duncan Kennedy and Martti Koskenniemi opened up these observations to the terrain of the political. Their work married ideology critique, law's 'deep' conceptual structure, the multi-directionality of power and the inescapability of choice. For them, the domination of law and its conceptual categories was hidden. We were unable to see the basic contestability of (international) law. An exposition of its assumed conceptual structure and this structure's indeterminate fundamental contradictions opened up space to see both how power and domination may be hidden and exposed, and how law's power may both oppress and offer possibilities for strategic resistance. Above all it opened up the terrain of the political, where a lawyer's competence is measured against her ability to see these dynamics (or put another way, to grasp law's hegemonic and counterhegemonic moments) and to make normatively grounded, transparent choices in a conflictual legal community. Critical scholarship is constantly animated not only by these properties of power, but perhaps more so by a constant awareness that our legal concepts may flit between politics and the political. History, after all, teaches us that our apparently progressive legal concepts can, just as quickly as they are given life, become forces for domination, or even reified and perhaps placating categories. Even as it has fractured our notion of power (and hence politics) so that it is seen everywhere, critical scholarship persists in keeping our legal concepts open to the political - that is, showing them to be contingent and contestable, made by men with normative agendas, and capable of being remade by men. When our legal concepts ossify or possess us they must be patiently opened up to the realm of the political, over and over and ever more diligently.

Third, we arrive at ethics. Much as in the case of aesthetics and politics, our legal sensibilities often unconsciously assume an ethical stance towards the world. It turns out that our ethical postures towards legal concepts centre around precisely those identified in the first section of this chapter: mastery and therapy. The latter is apparent whether we chose to pursue a perfectly defined or delimited concept, or the 'correction' of legal reasoning through law's conceptual structure, or whether we seek the expulsion 
of legal concepts from the law in our quest to purify. Whether it appeared through philosophy, science or logic, Nietzsche and Adorno both knew of, and raged against, the irrepressible presence of mastery in our relation to concepts. ${ }^{106}$ It would seem that our legal sensibilities cannot do without the desire to control the world, even in their approaches to legal concepts. But every such attempt to impose concepts and conceptual structures seemed to be a failure: they could not direct, control or coerce social life. Epistemology governed ethics. And it turned out that international legal life had much more to do with that which could not be mastered, that which constantly eludes one's grasp - myth and magic. It was not enough to move towards life, for mastery remains in legal realism - whether it is the subtly assumed abstractions that foreclose any discussion of normative preferences, or the desire to reduce international legal life and legal concepts to social facts. It was only in the move from (or, rather, redefinition of) life to living that legal sensibilities laid the foundations for a therapeutic ethic. Conceptual work enabled living to become prior to knowledge; our ability to play with international law's indeterminate conceptual structures showed a form of living capable of both receiving the gift of the world and having the desire to transform it. The coercive properties of reason were paired with imagination. This was an epistemology driven by an ethics of inhabiting a shared world. It was, above all, therapeutic, for it sought confidence and professional competence, not certainty and correctness. International law is now full of legal sensibilities that pursue a therapeutic ethic: whether it is by working on concepts historically, so that we may be able to expand our horizons of expectation while tethered to our experiences; ${ }^{107}$ or whether it is the philosophical work of questioning concepts with the desire to unfold and live in their multiplicity; ${ }^{108}$ or whether it is working on international legal concepts ideologically, so we cannot be possessed by them and instead have the fortitude to untether them from domination and pursue them to live up to their promises. ${ }^{109}$

It may then be wholly unsurprising to note that we end where we began. We can only trust that we have advanced a critique that urges us to be a little more hopeful and a little more confident in the fragile resources of our shared culture.

\section{CONTENTS OF THIS BOOK}

This book is only a modest beginning - and an experiment. In this section we would like to give order to the playfulness of our experiment, to justify some of our choices of

106 Adorno (n 82) 12 (speaking of the 'autarky of the concept'); F. Nietzsche, 'On the Genealogy of Morals' in F. Nietzsche, Basic Writings of Nietzsche (W. Kaufmann ed and tr, Modern Library 2000) 449.

107 See eg R. Koselleck and M. Richter, 'Introduction and Prefaces to the "Geschichtliche Grundbegriffe"" (2011) 6 Contributions to the History of Concepts 1; R. Koselleck, Futures Past: On the Semantics of Historical Time (K. Tribe tr, Columbia University Press 2004); Skinner, Visions of Politics (n 93) 175; Koskenniemi, 'Sovereignty' (n 101).

108 See eg Prost (n 6); G. Deleuze and F. Guattari, What Is Philosophy? (H. Tomlinson and G. Burchell III trs, Columbia University Press 1996) ('The philosopher is the concept's friend; he is the potentiality of the concept': ibid 5).

109 See n 102 of this chapter. 
concepts and to offer a series of frames through which the reader can view the following chapters.

We begin with the book's object of research: concepts. These are distinguishable from words in a number of respects. As Reinhart Koselleck formulated it, a 'concept may be attached to a word, but it is simultaneously more than that word'.110 A concept seems to always remain ambiguous within and beyond the context of its immediate 'it'. It is ambiguous in a different manner than words. A concept's internal ambiguity arises in part because it 'combines in itself an abundance of meanings', ${ }^{111}$ and in part because it is 'the point of coincidence, condensation or accumulation of its own components' ${ }^{112}$ But a concept's ambiguity also arises out of its external relativity, or rather its ever shifting relations to other concepts and its corresponding vocabulary. ${ }^{113}$ It serves as a relay for the movement of a conceptual world. If we want to grasp the worlds of international law which its practitioners see, we need to look at their concepts and not their words. ${ }^{114}$

Moreover, we are concerned with concepts for international law. This book, as has been noted, was conceived of, written and shaped in the midst of disciplinary malaise. But this contemporary condition is not merely an abstract context, one among many; it is that for which this book was compiled, not so that we may assuage our anxiety about our loss of common language, the fracturing of our common world and the accompanying loss of dialogue, community and meaning. Rather, we wished to put a series of questions to the concepts we find in today's discipline. How have our concepts been affected and changed? How have concepts and conceptual matrices been displaced or provoked? Has the porosity of our disciplinary boundaries introduced new concepts or altered existing 'legal' ones? How have international law's concepts registered and participated in its historical changes? Have our concepts changed our ability to contemplate, reflect and communicate within our discipline's shared world? Our task, and that of our authors, was, in short, to pose questions of our concepts and their possibilities.

But how did we choose our concepts? Our angle of engagement was framed by the historical period and geography of European modernity (and late modernity). ${ }^{115}$ The concepts we chose would be those that belonged to the domains of international law only by virtue of this history. Against this backdrop, two broad substantive considerations governed those concepts which we would choose to examine: first, historically

\footnotetext{
110 Koselleck (n 107) 19.

111 ibid 20; see also Deleuze and Guattari (n 108) 15.

112 ibid 20 (though 'what is distinctive about the concept is that it renders components inseparable within itself' at 19); see also Koselleck (n 107) 20.

113 Deleuze and Guattari (n 108) 21; a similar but nevertheless different argument is made in Q. Skinner, 'The Idea of Cultural Lexicon' in Skinner (n 96) 158, 160 (on the emergence of a corresponding vocabulary when a concept is possessed by a group and critiquing Raymond Williams' easy elision of words and concepts).

114 ibid 159.

115 Influenced by the common presupposition that, for better or worse, international law emerged as a project of European modernity and the parallel hypothesis offered by Koselleck that concepts came to a central role in social life and the domains of power during the Sattelzeit: see Koselleck (n 107) 9-15.
} 
significant concepts that registered and participated within large transformations of the international legal project; 116 second, concepts used by international lawyers to reflect upon the field as a domain of knowledge and theory. ${ }^{117}$

In addition to or as a subset of these broader substantive categories, narrower categories were used to identify the concepts you find in this volume: (1) designations of important and dominant actors; ${ }^{118}$ (2) core concepts used in legal argument and judicial reasoning; (3) terms used to designate influential and dominant projects; ${ }^{119}$ (4) core temporalized concepts in international law. ${ }^{120}$

As well as these substantive considerations, it became necessary to ask which types of concepts we wished to include in the book. Being familiar with Koselleck's basic concepts and Raymond Williams' keywords, we sketched some broad considerations that influenced which various types of concepts we wished to analyse.

Our first broad substantive concern (and to some degree our second) demanded that we examine those concepts that were 'indispensable' to the international legal project; these came close to Reinhart Koselleck's basic concepts in that the terms were essential to a given period in international law's history, and that in addition, while they were always controversial and contested, without them communication was not possible. ${ }^{121}$

Our second substantive concern meant that we were concerned with those concepts that appeared essential to certain forms of thought; this came close to one aspect of Williams' keywords. ${ }^{122}$

Both of these concerns, and our broader disciplinary moment, meant we wished to pay special attention to those concepts that possess us, that make an intimate claim upon us (such as rights, justice, humanity); in this we were guided by Heidegger's understanding of a basic concept as that which establishes a 'relation to the ground' on which we stand and which allows us to 'come in proximity with what strikes us essentially and make[s] a claim upon us'. ${ }^{123}$

116 See chapters on authority, civilization, compliance, consent, constitutionalisation, democracy, development, domination, effectiveness, ethnicity, fragmentation, hegemony, humanity, imperialism, individual, international community, international crime, jurisdiction, justice, legality, legitimacy, personality, progress, responsibility, rights, rule of law, sovereignty, state, universalism, war.

117 See chapters on analogy, autonomy, bindingess, coherence, discourse, domination, epistemic communities, ethics, faith, identity, ideology, imagination, indeterminacy, instrumentalism, interdisciplinarity, interpretation, interpretivism, legal dilemma, legal form, legality, legitimacy, normativity, pluralism, precedent, progress, reason, relative normativity, semantic authority, system.

118 See chapters on the critic, individual, international community, international organizations, revolutionaries, state, the utopians.

119 See chapters on constitutionalization, pluralism, universalism.

120 See chapters on civilization, constitutionalization, democracy, development, faith, fragmentation, imperialism, progress, revolutionaries, the utopians, war.

121 See Richter (n 107) 3; R. Koselleck, 'A Response to Comments on the Geschichtliche Grundbegriffe' in H. Lehmann and M. Richter (eds), The Meanings of Historical Terms and Concepts. New Studies in Begriffsgeschichte (German Historical Institute 1996) 62, 64.

122 R. Williams, Keywords: A Vocabulary of Culture and Society (Oxford University Press 1976) 15.

123 M. Heidegger, Basic Concepts (G. Aylesworth tr, Indiana University Press 1998) 16. 
Finally, throughout both substantive strands there was a concern that we may be concerned with concepts that are necessarily related to the wrong state of affairs; in this we were guided by the idea of legitimate concepts in the work of Theodor Adorno. ${ }^{124}$

As a matter of structure and organization, two observations must be noted. First, we have chosen to organize the chapters of the book alphabetically. It seemed partial and incomplete in any other arrangement. Second, we have also chosen to extensively cross-reference the concepts contained in the book. This is to reemphasize, over and over, the complexity of the relationships between them. Though we have certain conceptual pairings (critic/utopian, legality/justice, reason/faith), we have decided to prioritize complexity over canonical opposites.

These are, in sum, our strategic choices in compiling this volume. They have directed its shape and final form, for better or worse. But of course there are a great number of concepts that ought to have been included - think of corporations, civil society, history, liberalism, peace, time, transparency, and many more besides. We were no doubt hampered by issues of space, author availability and the limits of our imagination. Nevertheless, the authors of the chapters in this volume take up their task with verve. Though no theoretical frame or method was imposed on them (they were simply provided with a sample text on conceptual history), they have brought many novel ways of approaching the concepts considered in international law, as well as their possibilities. And in doing so, they have lived up to our hope that this volume, in the end, will offer invaluable insight into how international lawyers can live in a fragile discipline, simultaneously shaping and transforming it, through their imaginative work on its concepts.

124 Adorno (n 82). 